\title{
Free fat transplants around the spinal dura
}

\author{
Yasumasa Shirai, Tadaatsu Ito, Yoshito Nakayama, \\ Yasuji Matsumoto, Takuo Onoda, and Kyoichiro Ii \\ Department of Orthopedics, Nippon Medical School
}

Many patients with spinal canal stenosis or intervertebral disk herniations have been successfully operated on. In some cases, however, after a successful operation, sevral clinical symptomes appeared that made us suspect post-operative scar formation. As a matter of fact, after an operation on the lumber spine, there is usually a firm scar ${ }^{1,2)}$, the so-called the laminectomy membrane, adherent to the spinal dura and its surrounding tissues. The purpose of this paper is to report the clinical and experimental results of free fat transplants placed on the spinal dura after an operation on the lumbar spine in order to prevent the excessive scar formation. The present paper is based on the data obtained from 28 cases of lumbar intervertebral disk herniations and 10 cases of spinal canal stenosis. In all cases, the operation was carried out in our clinic from 1977 to 1978 . The operated patients were all examined myelographically 4 or 5 weeks after the operation, as well as before the operation. There were 26 males and 12 females ( 38 in total) who ranged in age from 22 to 74 years. In 28 patients, free fat transplants were placed on the denuded part of the dura before the closure of the operated wound. These free fat tissues were obtained from the subcutaneous fat layer in the back during the operation.

All patients were examined during the post-operative period by means of straight-legraising test as well as by observing muscle spasm in the hamstrings, tenderness over superior gluteal nerve, lumbago, foot pain, intermittent claudication and myelograms. Myelograms were taken 4 or 5 weeks after the operation. Myelographic observations were especially focussed on the posterior side of the dural column where the fat tissue was placed.

Table 1 Clinical features at six months after an operation

\begin{tabular}{|c|c|c|c|c|c|c|c|}
\hline $\begin{array}{l}\text { Intervertebral } \\
\text { disk herniations }\end{array}$ & SLR & $\begin{array}{l}\text { Hamstring } \\
\text { spasm }\end{array}$ & $\begin{array}{l}\text { Sup. Gl.N. } \\
\text { tenderness }\end{array}$ & Lumbago & Foot pain & $\begin{array}{l}\text { Intermittent } \\
\text { claudication }\end{array}$ & $\begin{array}{l}\text { Indentation on } \\
\text { myelogram }\end{array}$ \\
\hline Fat transplants & 0 & 0 & 0 & $\begin{array}{l}1 \text { case } \\
(5.5 \%)\end{array}$ & $\begin{array}{l}1 \text { case } \\
(5.5 \%)\end{array}$ & 0 & $\begin{array}{c}6 \text { cases } \\
(28.5 \%)\end{array}$ \\
\hline No fat transplants & $\begin{array}{l}1 \text { case } \\
(16.6 \%)\end{array}$ & $\begin{array}{l}2 \text { cases } \\
(33.3 \%)\end{array}$ & $\begin{array}{l}1 \text { case } \\
(16.696)\end{array}$ & $\begin{array}{l}3 \text { cases } \\
(50.0 \%)\end{array}$ & $\begin{array}{l}1 \text { case } \\
(16.6 \%)\end{array}$ & 0 & $\begin{array}{l}1 \text { case } \\
(14.2 \%)\end{array}$ \\
\hline \multicolumn{8}{|l|}{ Spinal canal stenosis } \\
\hline Fat transplants & & $\begin{array}{l}1 \text { case } \\
(16.6 \%)\end{array}$ & $\begin{array}{l}1 \text { case } \\
(16.6 \%)\end{array}$ & 0 & $\begin{array}{l}1 \text { case } \\
(16.6 \%)\end{array}$ & 0 & $\begin{array}{l}1 \text { case } \\
(14.2 \%)\end{array}$ \\
\hline No fat transplants & & 0 & $\begin{array}{l}1 \text { case } \\
(1009)\end{array}$ & 0 & 0 & 0 & 0 \\
\hline
\end{tabular}

Present address : Department of Orthopedics, Nippon Medical School, 1-1-5, Sendagi, Bunkyo-ku, Tokyo, 113 Japan 
The changes in clinical features during 6 months after the surgery are shown in Table 1. The table shows that the free fat transplants appeared to produce unfavorable results at 3 months after the surgery. However at 6 months after the operation, the fat transplants obviously became producing favorable results. According to the lateral views of the myelograms which were taken in standing posture with the trunk extended, in $28.5 \%$ of patients with fat transplants, there was the indentation on the posterior site of the spinal dura at the level where the fat transplant was placed.

To pursue the fate of free fat transplants histologically, we have performed experiments on nine rabbits. In each rabbit, total laminectomy was carried out at two levels of the vertebrae, leaving one intact lamina between the two laminectomized sites. In one of the laminectomized site, a piece of subcutaneous fat tissue from the neck was placed on the denuded dura while the other laminectomized site was left to its own fate, as control, and was usually filled with blood coagula. The rabbits were sacrificed at 1 to 17 weeks after the operation. Microscopic sections were made from both laminectomized sites. Each section was stained with the method of Masson Trichrom.

At 2 weeks after the operation, the fat tissue and the dura appeared microscopically normal, but there were moderate inflammatory changes. In the case of no fat transplants, at 5 weeks after the operation, the dura exhibited a marked proliferation of the fibrous connective tissue which was adherent to the dura. By examining the several sections at 8 , 11 and 17 weeks after the operation, it was demonstrated that the extent of adhesion spreaded extensively as the passage of time. On the other hand, in the case of fat transplants at 17 weeks after the operation, there was degenerative fat tissue appearing as irregularly shaped droplets. There was infiltration of reticulous fibers into the fat tissue and a part of the dura was sharply circumscribed with slight adherent (Fig. $1 \mathrm{~A}$ ).

The section at 17 weeks after an operation revealed that the transplanted fat was retained in the previously operated space without extensive adherent to the dura. These results were almost the same as those described by Langenskiold ${ }^{2)}$ in 1976 as far as animal experiments were concerned. However, no histological work has been so far

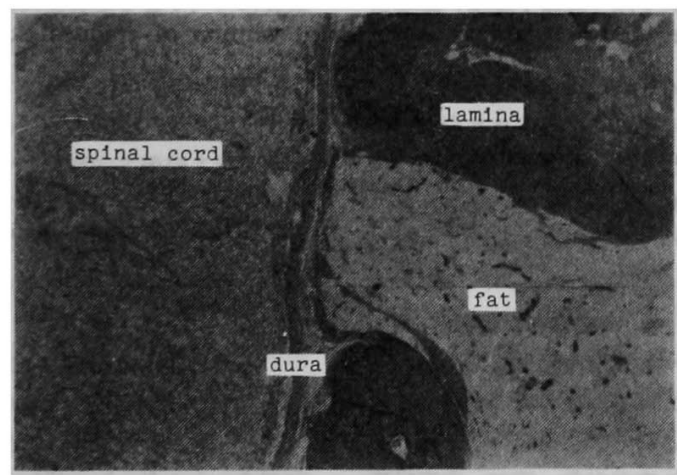

Fig. 1 A Photomicrograph of the laminectomy site 17 weeks after an operation with free fat transplants. 


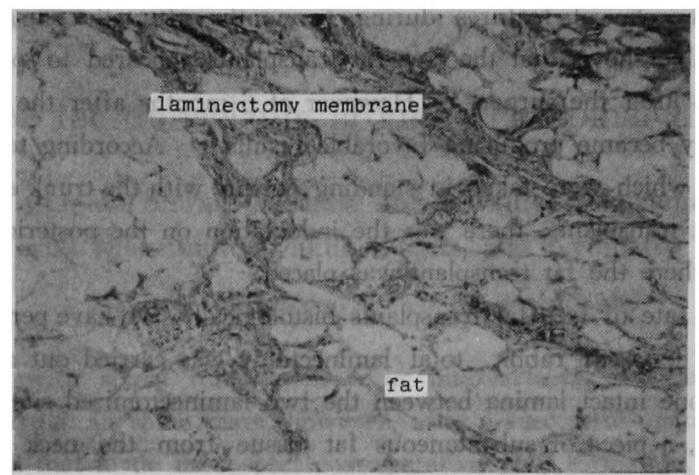

Fig. 1 B Photomicrograph of the laminectomy membrane and transplanted fat tissue from human epidural space which were placed on 9 months previously.

done to observe the fate of transplanted fat tissue in the human epidural space. We report here a case with successfull removal of previously transplanted fat tissue from a human epidural space. A 37-year-old man had a Love's operation 9 months previously for disk prolapse between L 5 and $\mathrm{Sl}$ and free fat was transplanted on the dura. He was examined again in March 1978, because of his right sciatic pain. He was diagnosed as having intervertebral disk herniation between L 4 and L 5. A second operation was carried out in April 1978. The fat tissue was found to have retained almost normal appearance without adherent to the dura at the previously operated space into which fat was transplanted. The fat transplant was histologically studied. The histological section of the laminectomy membrane revealed a retained fat tissue and fibrous connective tissue with dense collagen fibers which were proliferated into the fat droplets, as seen in Fig. 1 B.

It was thought that these degenerated fat droplets, which were irregular in size, was first infiltrated by the reticulous fibers and then replaced with the connective tissue. These clinical and histological results suggest that production of the laminectomy membrane may be completed within 6 months after the operation. From these results, it is reasonable to assume that the free fat transplant is useful in prevention of epidural scar formation.

\section{REFERENCES}

1) Lexer, E. : Stuttgart, Ferdinand Enke, pp. 264 545, 1919.

2) Langenskiold, A., and Kiviluoto, O. : Clin. Orthop., 115, 92 95, 1976.

(Received for publication, December 22, 1980) 